\title{
Export Structure, FDI and Child Labour
}

\author{
Matthias Busse and Sebastian Braun \\ HWWA Hamburg Institute of International Economics
}

\begin{abstract}
The paper addresses the linkage between certain aspects of the increasing economic integration of world markets and the level of child labour. We empirically examine, first, the often-cited conventional wisdom that multinational enterprises invest in countries where the extent of child labour is relatively high and, second, the concern that countries may gain an unfair comparative advantage in trade by using child labour. The results indicate that multinationals are highly sensitive with respect to the location of their transplants and prefer countries with lower levels of child labour. The opposite outcome applies to child labour and comparative advantage in labour-intensive goods, where we find a statistically significant positive relationship. Based on these results, the paper also discusses some policy implications on how to deal with child labour effectively.
\end{abstract}

- JEL Classification: C31, F15, J82

- Key words: Child Labour, Economic Integration, Trade, FDI

\section{Introduction}

The successful elimination of child labour throughout the world is probably one of the most important policy objectives of our time. The size and shape of the problem are of enormous proportions. According to recent estimates by the International Labour Organisation (ILO), there are more than 245 million child

\footnotetext{
*Corresponding address: Matthias Busse, Hamburg Institute of International Economics (HWWA), Department World Economy/Abteilung Weltwirtschaft, Neuer Jungfernstieg 21, D-20347 Hamburg, Germany, Tel: +49-(0)40-42834-435, Fax: +49-(0)40-42834-451, E-mail: busse@hwwa.de (C)2004-Center for International Economics, Sejong Institution, All Rights Reserved.
} 
labourers worldwide. ${ }^{1}$ Yet the magnitude of the tragedy and human suffering is not captured by an aggregated number alone. Conditions of children at work vary significantly. Some of them are at very high danger, as they work in hazardous industries under appellant working conditions, risking accidents and injuries. It has been estimated that some 180 million adolescents are subject to the "worst forms" of child labour, those that are inexcusable under any circumstances (ILO, 2002). This amounts to one child in every eight in the world.

The child labour problem is particularly severe in the Asia-Pacific region and sub-Saharan Africa, where on average 19 and 29 per cent of the children aged 514 , respectively, are economically active. In some countries, such as Burundi and Mali, it has been estimated that approximately half of the total child population (aged 10-14) are at work. Consequently, child labour amounts to a significant proportion of the total work force in poorer countries. Estimates suggests that child workers account for more than 7 per cent of the total labour force in developing countries, with even higher numbers in Africa (ILO, 2002; World Bank, 2002).

The causes and economic consequences of child labour have been analysed in depth by Basu and Van (1998), Brown, Deardorff and Stern (2001), as well as by Baland and Robinson (2000). ${ }^{2}$ Moreover, regarding the empirical evidence on the effects of child labour, most studies focused on human capital levels, GDP growth rates or the determinants of child labour itself. ${ }^{3}$ Obviously, child labour is detrimental to economic development, as it means that the next generation of workers will be less well educated and, hence, less skilled. Lower human capital levels then are likely to affect GDP growth rates negatively.

Yet there is also concern that countries which use (or allow) child labour may increase their (cost) competitiveness and, thus, influence trade flows or may attract more foreign direct investment (FDI). In this respect, child labour has been discussed within a wider range of topics related to labour standards in general, which also include forced labour, union rights and discrimination in employment. Concerns have been raised that there might be a "race to the bottom" on such standards (Palley, 2002). To ensure a level playing field, developed countries like the European Union countries have demanded binding rules within the framework

\footnotetext{
${ }^{1}$ See the most recent ILO report on child labour (ILO, 2002). The figure applies to the year 2000.

${ }^{2}$ In fact, these three are some of the more recent studies only. See Brown, Deardorff and Stern (2001) for a survey of the fast-growing literature.
}

${ }^{3}$ See, for instance, Barro (1997), Sala-i-Martin (1997), Hussain (1999) or Shelburne (2001). 
of the World Trade Organisation (WTO) that deal effectively with labour standards. Tensions on the issue of labour standards, including child labour, have increased significantly over the last couple of years. For instance, a failure to include that topic in a new round of trade negotiations contributed to the breakdown of the WTO trade talks in Seattle in 1999. Later on, in November 2001, the European Union still insisted on the inclusion of labour standards in the new multilateral trade round, but this second attempt was also rejected by developing countries, which fear that high-income nations will try to excuse protectionist measures against foreign competition by alleging their rivals use, say, child labour.

Given that the issue of child labour ranks relatively high on the international policy agenda, it is rather surprising that there is little empirical evidence on the linkage between the increasing economic integration of the world economy ${ }^{4}$ and the extent of child labour. In fact, five studies have addressed the relationship between trade and child labour or FDI and child labour. ${ }^{5}$ The first empirical attempt was made by Rodrik (1996), who focused on the ratio of textile and clothing exports to total exports, but did not find a statistically significant link to his measure of child labour. Busse (2002), on the other hand, indicated that comparative advantage and the extent of child labour might be associated to some extent, but concentrated his analysis more on labour standards in general. Mah (1997) regressed export shares of GDP on the ratification of fundamental ILO conventions and found that they are negatively correlated. Yet he did not incorporate any indicator that measures compliance with rather than ratification of ILO conventions

Regarding the link between FDI inflows and child labour, Cooke and Noble (1998) concentrated on the relationship between the number of ratified ILO conventions and United States FDI abroad. They found a positive and statistically significant relationship between the two, which implies that US companies favour countries with a stronger record of ratifications of ILO conventions as an

\footnotetext{
${ }^{4}$ In general, the term "economic integration" refers to the reduction of market segmentation and an increasing interdependence of national markets, that is, a closer integration of production and markets, which includes not only trade and capital flows, but also the movement of workers. Regarding the main focus of this paper, we concentrate the following analysis on the linkage between child labour and trade flows/FDI.

${ }^{5}$ Apart from trade and FDI, most of the empirical studies mentioned in this section have also examined the interaction between child labour and other economic variables like wages or other labour standards and trade/FDI. For the purpose of this paper, only their results with respect to child labour and trade/FDI are reported.
} 
investment location. Similar to Mah, they did not include any indicator that focuses on the observance of these conventions. In contrast, Kucera (2002) regressed a number of indicators for the observed extent of influence child labour has on FDI inflows, but his results were not statistically significant. To sum up, the empirical evidence available in the literature has been rather inconclusive.

Apart from these empirical studies there is some anecdotal evidence of international linkages between the use of child labour and trade/investment. In India, Pakistan and Nepal, for instance, it has been reported that children have been used for the production of carpets, textiles and/or clothing (Bales, 2000). Since these commodities are (partly) exported to North America and Europe, national and international competitors are worried about an unfair cost advantage, as children are paid very low wages (Brown, 2000). Moreover, multinational enterprises are frequently accused by non-governmental organisations of employing child labour in their oversees production facilities. ${ }^{6}$

Against this background, the paper focuses on three issues: (1) whether child labour affects FDI flows; (2) whether child labour is closely associated with the structure of trade flows, that is, comparative advantage in particular in commodities that use a higher extent of child labour; and (3) how to deal with child labour. In the following section, child labour is defined and the corresponding ILO conventions are introduced. Section 3 considers the data, that is, how to measure child labour, and presents the indicators used in the regressions. The results of the empirical analysis of the linkage between child labour and FDI/ comparative advantage are reported in Section 4. Finally, some policy implications on how to deal with child labour and concluding remarks are found in Section 5.

\section{Definition of Child Labour and ILO Conventions}

In order to analyse the problem of child labour effectively, the term itself should be clarified first. Generally, child labour refers to work that is exploitative and detrimental to the development of the child. This definition excludes activities such as light work after school and takes into account that work does not necessarily jeopardise the development of young people and can even be advantageous for them. The ILO (2002) identifies three categories of child labour to be abolished in

\footnotetext{
${ }^{6}$ See, for example, reports by Amnesty International (2002) on the behaviour of multinational enterprises in developing countries.
} 
its Global Report on the issue:

(a) Labour performed by a child who is under a minimum age, specified in national legislation for that kind of work.

(b) Hazardous work that compromises the physical, mental or moral well being of a child.

(c) The unconditional worst forms of child labour, which include slavery, debt bondage and similar practices, sex work, and illicit activities.

This classification reflects the provision of the ILO conventions on child labour. Convention No. 138, adopted in 1973, aims at the establishment of a minimum age for child work consistent with the development and maturity of young persons. Therefore, it stipulates that the minimum age for admission to employment should not fall short of the age of completion of compulsory schooling and should not be less than 15 years. ${ }^{7}$ Having attracted only 72 ratifications by then, ${ }^{8}$ the ILO adopted a new convention (No. 182) in 1999, focusing on the most harmful forms of child labour. The convention calls for immediate action to ban the worst forms of child labour, namely hazardous work and the unconditional worst forms of child labour as defined above.

The Worst Forms of Child Labour Convention is the fastest ratified in the history of the ILO. As of 31 December 2002, 132 countries had ratified Convention No. 182, while ratifications of Convention No. 138 had reached a total of 120 (ILO, 2003). Although these numbers clearly represent the fast-growing consensus concerning the elimination of abusive child labour, the conventions on child labour have still attracted fewer ratifications than the conventions on the other fundamental rights at work the ILO focuses on in its Declaration on Fundamental Principles and Rights at Work (ILO, 1998). ${ }^{9}$ Note, however, that an ILO member state has to respect the abolition of child labour as one of the principles concerning the core labour standards, even if it has not ratified the respective convention.

In order to enforce compliance with the conventions, the ILO relies primarily on

\footnotetext{
${ }^{7}$ Depending on the social and economic situation, developing countries may be allowed to set the minimum age at 14 years.

${ }^{8}$ See ILO (2003).

${ }^{9}$ The remaining principles concerning the fundamental rights are freedom of association and the effective recognition of the right to collective bargaining, the elimination of all forms of forced or compulsory labour and the elimination of discrimination in respect of employment and occupation.
} 
a supervisory mechanism and especially on technical assistance. Consequently, the International Programme on the Elimination of Child Labour (IPEC), initiated by the ILO, concentrates its efforts on the reinforcement of national capacities and the formation of a global movement against child labour. Nevertheless, Article 33 of the ILO constitution also authorises the ILO to take action against member states that do not comply with recommendations made by a Commission of Inquiry established to examine grave violations of ILO conventions (ILO, 1989)..$^{10}$ In 2000, the Article was invoked for the very first time in the case of Myanmar, where military authorities force civilians, many of them children, to perform unpaid work.

\section{Measures of Child Labour}

For a long time there were virtually no reliable data on child labour available. Although the situation has improved in recent years, as many countries and in particular the ILO have undertaken surveys to investigate child labour, totally accurate measures of the extent of child labour are still not at hand. The major difficulty lies in counting the many children that are working in the informal economy, in family enterprises or illegal and hidden activities. Against this background, we will use multiple measures to quantify the level of child labour in each country. This approach provides a test of robustness, since the various indicators are prone to different types of measurement errors. More specifically, four indicators will be introduced: three to compute the extent of child labour, namely the de facto observance of the ratified conventions, and one to measure the de jure ratification of the ILO conventions on child labour.

The first variable is called CHILD1, representing the ILO estimates on the labour force participation rate of children. In fact, CHILD1 measures the nonprevalence of child labour, that is, the percentage of children, ages 10-14, who are not working. Defining CHILD1 exactly opposite to the ILO ensures a straightforward interpretation of the subsequent results, as a higher number in any of the four indicators implies a higher standard (or less child labour) ${ }^{11} \mathrm{Next}$, for the gross secondary school enrolment rate (in per cent), SECSCHOOL will be used. Secondary education completes the provision of basic education that began at the primary level, and usually relates to the age group of 10 to 15 years. Though

\footnotetext{
${ }^{10}$ See Section 5 for more details on ILO actions against member states.

${ }^{11}$ Data sources of all variables can be found in Appendix A.
} 
Table 1. Correlation Matrix

\begin{tabular}{lcccccc}
\hline \multicolumn{1}{c}{ Variable } & CHILD1 & CHILD2 & $\begin{array}{c}\text { SEC- } \\
\text { SCHOOL }\end{array}$ & $\begin{array}{c}\text { CON- } \\
\text { VENTION }\end{array}$ & DEMOCRACY GDP \\
\hline CHILD1 & 1.00 & & & & & \\
CHILD2 & 0.53 & 1.00 & & & \\
SECSCHOOL & 0.78 & 0.63 & 1.00 & & & \\
CONVENTION & -0.01 & 0.13 & 0.11 & 1.00 & 1.00 & \\
DEMOCRACY & 0.38 & 0.40 & 0.54 & 0.24 & 0.65 & 1.00 \\
GDP & 0.43 & 0.66 & 0.65 & 0.16 & & \\
\hline
\end{tabular}

Notes: Own calculations; see Appendix A for data sources.

the non-prevalence of child labour and school attendance are highly correlated (see Table 1), SECSCHOOL may act as a helpful complement to CHILD1, as both indicators can be problematic. For instance, children who are not attending school do not automatically work. Also, some children have to work to finance their school attendance. By employing both indicators, the inevitable measurement error in each of them is thus likely to be minimised.

The third variable is CHILD2, representing the indicator for the degree of child labour as suggested by Rodrik (1996). He assessed each country as to whether there are shortcomings either in legislation or enforcement. Insufficiencies in legislation relate to non-existing child labour regulations or to provisions in national laws that are incompatible with the two ILO conventions. Inadequacies in enforcement refer to a lack of government staff or readiness to ensure existing legislation in practice. Rodriks assessment has been updated and complemented with the extensive ILO (2002) report on child labour as well as information provided by the US Department of State (2002). Drawing on these sources, the following numbers have been used for CHILD2: a 2 if there are no reported problems with either legislation and enforcement, 1 if there are insufficiencies with only one of them, and 0 if there are inadequacies with both of them. ${ }^{12}$

The fourth variable is CONVENTION, representing the total number of ratifications of the two child-labour conventions of the ILO. Accordingly, CONVENTION ranges from zero (no child-labour convention ratified) to two (both child-labour conventions ratified). Since Convention No. 182 was set up as recently as November 1999, member countries have ratified this convention successively. To ensure an accurate number of ratifications, CONVENTION relates

\footnotetext{
${ }^{12}$ The assigned numbers for each country can be found in Appendix B.
} 
thus to the number of ratified conventions in December 2002, while the first three child-labour indicators are based on data for the year 2000, the latest year for which the data was available.

The number of ratified ILO conventions on child labour appears to be a poor measure of the level and extent of child labour. The computed partial correlations between the number of ratifications for the two conventions and the three indicators for child labour in the range between -0.01 and 0.13 are rather low (Table 1). Sometimes the interpretation or exact phrasing of the child-labour conventions contradicts national laws or regulations (OECD, 1996, 2000). On the other hand, ratifying a particular convention does not automatically imply its thorough observance. For instance, while Rwanda has ratified both conventions, it has a severe child labour problem, whereas the United States has ratified only one, but does not have any troubles with child labour in practice (ILO, 2002).

All four child labour indicators are positively correlated with GDP per capita, indicating that higher income levels are associated with a lower extent of child labour. This strengthens the impression that poverty and underdevelopment are probably the most important determinants of child labour. ${ }^{13}$ On the other hand, CHILD1, CHILD2 and SECSCHOOL might act as substitutes for other country characteristics that have not been considered so far. These might comprise certain economic, social or political circumstances, thereby leading to biased regression results. Though these other determinants are obviously difficult to measure, we have tried to control for the widest possible range of additional factors. Accordingly, the two Freedom House (2002) indicators for civil liberties and political rights, which deal with a relatively extensive scope of all kinds of basic human and political rights, have been included in the (FDI) regressions.

Both Freedom House indicators are measured on a scale of 1 to 7 , where higher numbers imply fewer liberties and rights. To reduce the problem of multicollinearity between two highly correlated variables, both are merged to DEMOCRACY:

$$
\text { DEMOCRACY }=\frac{14-(\text { Political Rights }+ \text { CivilLiberties })}{12}
$$

This transformation has been suggested by Helliwell (1994) and will lead to a single indicator, which varies from 0 (no political rights and civil liberties) to 1

\footnotetext{
${ }^{13}$ See the empirical evidence presented by Shelburne (2001), but also more recent studies by Cigno et al. (2002) or Edmonds and Pavcnik (2002).
} 
(complete set of political rights and civil liberties). Considering the partial correlations in a range between 0.38 and 0.54, CHILD1, CHILD2 and SECSCHOOL are correlated to some degree with this synthetic indicator.

\section{Empirical Evidence}

Following the introduction of the four measures of the extent of child labour, we now turn to the linkage between these indicators and FDI and trade flows. As the dependent variable in the foreign direct investment regressions, average FDI inflows per capita during the period 1995 to 2000 have been chosen. The focus is on FDI flows rather than stocks, given that FDI stocks correspond to flows over a longer period and the indicators for child labour are relatively recent. ${ }^{14}$ Per capita FDI figures allow a control for the size of the country (population), while a period of six years has been chosen to take account of the fact that FDI flows for a single country may fluctuate considerably from year to year.

A standard starting point for choosing the independent variables of the model would be to use a standard theoretical model on the determinants of FDI flows, integrate a child labour variable and then estimate the effects. Regrettably, no such model exists. Over the last couple of decades, researchers who have studied the characteristics and behaviour of multinational enterprises have singled out-among others-specific management skills, innovative product technologies, economies of scale, labour costs, market size and growth, or political and economic stability as contributing factors in explaining why and where multinational enterprises invest abroad (Graham, 2000). The empirical evidence on the determinants of FDI flows shows that above all market size, market growth rates, and openness to trade are the most important determinants. ${ }^{15}$ For this reason, these three are included in the control regression: market size (the variable is called GDP) is quantified by GDP per capita, market growth (GROWTH) is measured as average GDP per capita growth in the period 1995-2000, and openness to trade, TRADE, representing the ratio of imports and exports to GDP. Moreover, as a control for other country and regional characteristics, DEMOCRACY and a full set of regional dummy variables (REGIONAL DUMMIES) have also been inserted in the benchmark regression. ${ }^{16}$

\footnotetext{
${ }^{14}$ Importantly, the following results do not vary to a large extent if FDI stocks are applied instead of flows.

${ }^{15}$ See Chakrabarti (2001) for a survey of the empirical studies.

${ }^{16}$ Included were all 132 countries that reported the data for all six variables. Similar to most studies on FDI flows, a semilog model has been used.
} 
In Table 2, the estimation results for five regressions are reported. As can be seen from the results for the benchmark regression in column 1, all four explanatory variables have the expected positive sign and are statistically significant at the 1 or 5 per cent level. ${ }^{17}$ In the remaining columns, the coefficients for the four child labour indicators are shown. To see whether child labour also influences FDI flows, each indicator is added one by one to the benchmark regression. CHILD1 and SECSCHOOL also have positive signs and are highly significant at the 1 per cent level. This implies that the observed prevalence of child labour is negatively associated with FDI flows. In other words: Countries

Table 2. Child Labour and Foreign Direct Investment, All Countries

\begin{tabular}{|c|c|c|c|c|c|}
\hline \multirow{2}{*}{$\begin{array}{l}\text { Independent } \\
\text { Variables }\end{array}$} & \multicolumn{5}{|c|}{ Dependent Variable: FDI } \\
\hline & (1) & (2) & (3) & (4) & (5) \\
\hline Constant & $\begin{array}{l}1.475 * * * \\
(0.310)\end{array}$ & $\begin{array}{l}-2.483^{*} \\
(1.411)\end{array}$ & $\begin{array}{l}1.762 \\
(1.157)\end{array}$ & $\begin{array}{l}1.126 \\
(1.040)\end{array}$ & $\begin{array}{l}2.152^{*} \\
(1.118)\end{array}$ \\
\hline GDP & $\begin{array}{l}0.115 * * * \\
(0.025)\end{array}$ & $\begin{array}{l}0.089 * * * \\
(0.024)\end{array}$ & $\begin{array}{l}0.097 * * * \\
(0.030)\end{array}$ & $\begin{array}{l}0.084 * * * \\
(0.025)\end{array}$ & $\begin{array}{l}0.115^{* * * *} \\
(0.026)\end{array}$ \\
\hline GROWTH & $\begin{array}{l}0.137 * * * \\
(0.044)\end{array}$ & $\begin{array}{l}0.153 * * * \\
(0.042)\end{array}$ & $\begin{array}{l}0.117 * * \\
(0.055)\end{array}$ & $\begin{array}{l}0.128 * * * \\
(0.041)\end{array}$ & $\begin{array}{l}0.136 * * * \\
(0.044)\end{array}$ \\
\hline TRADE & $\begin{array}{l}0.014 * * * \\
(0.002)\end{array}$ & $\begin{array}{l}0.009 * * * \\
(0.002)\end{array}$ & $\begin{array}{l}0.014^{* * * *} \\
(0.003)\end{array}$ & $\begin{array}{l}0.011 * * * \\
(0.002)\end{array}$ & $\begin{array}{l}0.014 * * * \\
(0.002)\end{array}$ \\
\hline DEMOCRACY & $\begin{array}{l}1.107 * * \\
(0.448)\end{array}$ & $\begin{array}{l}0.928 * * * \\
(0.420)\end{array}$ & $\begin{array}{l}1.273 * * \\
(0.586)\end{array}$ & $\begin{array}{l}0.749 * \\
(0.427)\end{array}$ & $\begin{array}{l}1.147 * * \\
(0.460)\end{array}$ \\
\hline CHILD1 & & $\begin{array}{l}5.347 * * * \\
(1.166)\end{array}$ & & & \\
\hline CHILD2 & & & $\begin{array}{l}0.328 \\
(0.243)\end{array}$ & & \\
\hline SECSCHOOL & & & & $\begin{array}{l}1.955 * * * \\
(0.489)\end{array}$ & \\
\hline CONVENTION & & & & & $\begin{array}{l}-0.059 \\
(0.139)\end{array}$ \\
\hline REGIONAL DUMMIES & Yes & Yes & Yes & Yes & Yes \\
\hline Adj. $R^{2}$ & 0.71 & 0.75 & 0.73 & 0.74 & 0.70 \\
\hline $\mathrm{N}$ & 132 & 128 & 104 & 131 & 132 \\
\hline
\end{tabular}

Notes: See Appendix A for data sources; standard errors, which have been checked for heteroskedasticity, are reported in parentheses; multicollinearity has been tested by the creation of variance inflation factors (VIF); all regressions pass the test at conventional levels; *** significant at $1 \%$ level; ** significant at 5\% level; * significant at $10 \%$ level.

${ }^{17}$ The coefficients for the six regional dummy variables have not been reported due to reasons of space. The results can be obtained from the first author upon request. 
with a lower level of child labour or higher secondary school enrolment rates received more FDI per capita in the period 1995 to 2000 than would have been forecasted on the basis of the other country characteristics. To give an example: A decrease of the extent of child labour by 1 percentage point would lead to an increase in FDI inflows by 5.3 percent. This is quite a large number, implying that the extent of child labour would have a significant and considerable impact on FDI flows. Yet we have to bear in mind that the estimated coefficients for CHILD1 and the other child labour variables may overstate the impact of these variables on foreign investment flows, since they are likely to act as a substitute for other important country characteristics, which are not included in the regressions.

Though the coefficient for CHILD2, as a further indicator for the extent of child labour, is also positive, it is not statistically significant. CONVENTION, measuring the de jure ratification of both ILO conventions on child labour, does not significantly affect FDI flows (column 5). The coefficient is even negative.

These results might have been influenced by the fact that FDI flows are dominated by high-income countries and regions. In the period 1995-2000, highincome OECD countries made up 74 per cent of global FDI inflows and some 83 per cent of outflows (World Bank, 2002; UNCTAD, 2002). For that reason, sign and significance of the coefficients of the child labour indicators might be biased. To check the robustness of the results, high-income and upper-middle-income countries have been eliminated in a second set of regressions. Only low-income and lower-middle-income developing countries, namely countries with a GDP per capita in 2000 of less than 2,995 US dollars according to a definition by the World Bank (2002), were included in the regressions. In this way, the focus is on poor developing countries only, where child labour is a problem of much higher importance in comparison to higher-income countries (Figure 1). In total, 85 developing countries have been singled out, representing an annual average of 77 billion US dollars or some 12 per cent of world FDI inflows in the period 1995 to 2000.

As can be seen in Table 3, the results of the additional set of regressions on FDI flows are very similar to those of the previous set. Even if the overall fit of the benchmark and the other regressions deteriorates somewhat, signs and statistical significance of all variables are very similar. Yet the statistical significance of SECSCHOOL worsens from the 1 to the 10 per cent level and the coefficient for CHILD2 becomes negative (though still not significant). In general, these results confirm those of the first set of empirical estimates, that is, the level of child labour 
Figure 1. Extent of Child Labour and Income Levels.

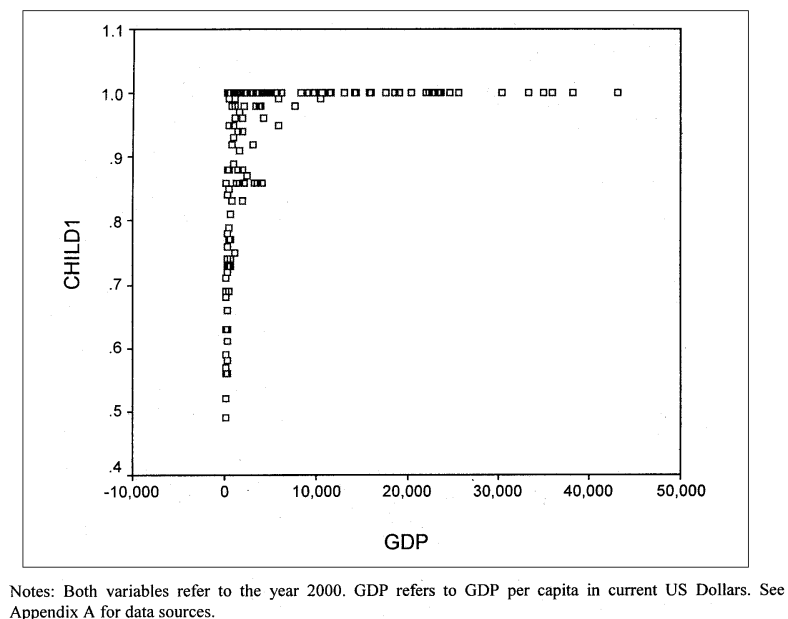
Notes: Both variables refer
Appendix A for data sources.

Table 3. Child Labour and Foreign Direct Investment, Developing Countries

\begin{tabular}{|c|c|c|c|c|c|}
\hline \multirow{2}{*}{$\begin{array}{c}\text { Independent } \\
\text { Variables }\end{array}$} & \multicolumn{5}{|c|}{ Dependent Variable: FDI } \\
\hline & (1) & (2) & (3) & (4) & (5) \\
\hline Constant & $\begin{array}{l}-1.049 \\
(1.053)\end{array}$ & $\begin{array}{l}-5.003^{* * * *} \\
(1.639)\end{array}$ & $\begin{array}{l}-1.819^{*} \\
(1.084)\end{array}$ & $\begin{array}{l}-1.764 \\
(1.133)\end{array}$ & $\begin{array}{l}-1.044 \\
(1.071)\end{array}$ \\
\hline GDP & $\begin{array}{l}0.599 * * * \\
(0.182)\end{array}$ & $\begin{array}{l}0.494 * * * \\
(0.179)\end{array}$ & $\begin{array}{l}1.093 * * * \\
(0.255)\end{array}$ & $\begin{array}{l}0.497 * * \\
(0.191)\end{array}$ & $\begin{array}{l}0.599 * * * \\
(0.183)\end{array}$ \\
\hline GROWTH & $\begin{array}{l}0.139 * * * \\
(0.047)\end{array}$ & $\begin{array}{l}0.146 * * * \\
(0.047)\end{array}$ & $\begin{array}{l}0.127 * * \\
(0.054)\end{array}$ & $\begin{array}{l}0.134 * * \\
(0.047)\end{array}$ & $\begin{array}{l}0.139 * * \\
(0.048)\end{array}$ \\
\hline TRADE & $\begin{array}{l}0.014 * * * \\
(0.003)\end{array}$ & $\begin{array}{l}0.009 * * \\
(0.004)\end{array}$ & $\begin{array}{l}0.017 * * * \\
(0.004)\end{array}$ & $\begin{array}{l}0.012 * * * \\
(0.003)\end{array}$ & $\begin{array}{l}0.014 * * * \\
(0.003)\end{array}$ \\
\hline DEMOCRACY & $\begin{array}{l}0.362 \\
(0.516)\end{array}$ & $\begin{array}{l}0.476 \\
(0.504)\end{array}$ & $\begin{array}{l}0.081 \\
(0.642)\end{array}$ & $\begin{array}{l}0.329 \\
(0.511)\end{array}$ & $\begin{array}{l}0.365 \\
(0.526)\end{array}$ \\
\hline CHILD1 & & $\begin{array}{l}4.506 * * * \\
(1.470)\end{array}$ & & & \\
\hline CHILD2 & & & $\begin{array}{l}-0.136 \\
(0.276)\end{array}$ & & \\
\hline SECSCHOOL & & & & $\begin{array}{l}1.312^{*} \\
(0.807)\end{array}$ & \\
\hline CONVENTION & & & & & $\begin{array}{l}-0.005 \\
(0.153)\end{array}$ \\
\hline REGIONAL DUMMIES & Yes & Yes & Yes & Yes & Yes \\
\hline Adj. $R^{2}$ & 0.56 & 0.60 & 0.62 & 0.57 & 0.56 \\
\hline $\mathrm{N}$ & 85 & 82 & 64 & 85 & 85 \\
\hline
\end{tabular}

Note: Developing countries can be classified as low- and lower-middle-income countries with a GDP per capita in 2000 of less than US \$2,995 (World Bank, 2002); see Table 2 for further notes; *** significant at $1 \%$ level; ** significant at $5 \%$ level; * significant at $10 \%$ level. 
is negatively associated with FDI flows whether the focus is on all countries or relatively poor developing countries only. ${ }^{18}$ Contrary to the frequent accusations of non-governmental organisations, it appears that on average multinational enterprises do care where they invest, i.e. in countries with a higher GDP and growth rates, lower trade barriers, improved democratic rights and less child labour. On the other hand, these results may be driven by international campaigns of non-governmental organisations, fighting multinationals that do not observe basic rules with respect to child labour. But without accurate and comparable data for longer periods, which are not available, there is no definite answer on the likely reasons for these results. ${ }^{19}$

Next, the linkage between child labour and international trade will be explored. It is rather unlikely that the use of child labour affects significantly the overall export performance of a country, but rather the structure of trade flows. More specifically, the impact is most likely to be felt in labour-intensive commodities that may use unskilled labour to a relatively large extent. The main focus regarding trade is, thus, on the linkage between child labour and the structure of trade flows or comparative advantage in unskilled-labour-intensive manufactured goods. ${ }^{20}$

For a start, consider a standard Heckscher-Ohlin trade model with two production factors, skilled and unskilled labour, and two products, software and toys. Assume that both countries produce both goods by using both factors, trade with each other and fully respect labour standards in the initial situation. Now consider an increase in child labour in only one country. In the short run, the number of additional workers will increase the endowment of unskilled labour and expand production possibilities with a bias towards the unskilled-labour-intensive good (toys). ${ }^{21}$ As the production of toys increases relative to that of software, the country (gains or) improves its comparative advantage in the production of toys. Moreover, in the case of a large country, the increased (export) supply of toys

\footnotetext{
${ }^{18}$ Also importantly, these results do not change significantly if the cut-off point regarding income levels (GDP) is set at a higher level, say, US $\$ 5,000$ per capita. For reasons of space, the results have not been reported.

${ }^{19}$ Though the ILO provides child labour statistics since 1970 (up to 1990, the data is only available for 10-year intervals), the latest estimates for 2000 are not always comparable with earlier estimates due to changes in ILO data collection (ILO, 2002).

${ }^{20}$ While the majority of the economically active children work in agriculture, fishing, hunting and forestry, a considerable proportion, in the range of 15 to 20 per cent, is employed in manufacturing and trade (ILO, 2002).
} 
causes their world market price to fall, representing a decline in the terms of trade of that country. ${ }^{22}$

Included in the regression analysis are those manufactured goods that have two features: a high-labour and a low-technology intensity, for example toys, clothing, textiles, clothing, and footwear, goods which are unskilled-labour intensive. ${ }^{23}$ The relative labour intensity is influenced by value added per worker, ${ }^{24}$ while information on technology intensities has been obtained from the OECD (2001) Science, Technology and Industry Scoreboard. The dependent variable in the model, EXPLABINT, is computed as the ratio of unskilled-labour-intensive exports to total exports. Since comparative advantage in a Heckscher-Ohlin model is influenced by relative factor endowments, two control variables are used: (1) LABDENSITY, representing the total labour force divided by land area, for the relative labour endowment; and (2) EDUCATION, the educational attainment index of the United Nations Development Programme, as a proxy for human capital levels. The first control variable is expected to be positively associated with comparative advantage in labour-intensive goods, whereas the latter is likely to be negatively correlated with EXPLABINT. ${ }^{25}$

The results of the benchmark regression, reported in column 1 of Table 4, show both explanatory variables with the expected signs and a statistical significance of 1 per cent. Then, each child labour indicator is singly added to the regression, to see whether child labour also influences comparative advantage. All three variables

\footnotetext{
${ }^{21}$ Modelling the effect of child labour as the accumulation of a production factor is simply applying the Rybczynski (1955) theorem.

${ }^{22}$ Note that trade and welfare levels in both countries are likely to increase due to the use of child labour in only one country. However, the deterioration in the terms of trade could offset the welfare gains from the growth in the unskilled labour force, thereby making the economy worse off. This phenomenon is called immiserizing growth (Bhagwati, 1958). Obviously, any increases in welfare levels are due to the structure of the model, as the use of child labour will increase production possibilities. Child labour itself is not incorporated in the utility function (OECD, 1996). Such an approach is far beyond the main focus of this part of the paper, that is, the linkage between child labour and comparative advantage, and therefore excluded from the analysis.

${ }^{23}$ All commodities and the corresponding SITC numbers are listed in Appendix B.

${ }^{24}$ The data on labour-intensive commodities has been taken from Tyers et al. (1987).

${ }^{25}$ Similar to the FDI regressions, all countries reporting data for the three variables have been included in the data set. The only exception is Singapore, which has an extremely high population density as a citystate. The base year for all variables is 2000 . Again, to control for other characteristics, regional dummy variables have been added to all regressions.
} 
Table 4. Child Labour and Comparative Advantage

\begin{tabular}{|c|c|c|c|c|c|c|c|}
\hline \multirow{2}{*}{$\begin{array}{c}\text { Independent } \\
\text { Variables }\end{array}$} & \multicolumn{7}{|c|}{ Dependent Variable: FDI } \\
\hline & (1) & (2) & (3) & (4) & (5) & (6) & (7) \\
\hline Constant & $\begin{array}{l}0.722 * * * \\
(0.171)\end{array}$ & $\begin{array}{l}0.615 * * * \\
(0.222)\end{array}$ & $\begin{array}{l}0.690 * * * \\
(0.232)\end{array}$ & $\begin{array}{l}0.719 * * * \\
(0.161)\end{array}$ & $\begin{array}{l}0.699 * * * \\
(0.173)\end{array}$ & $\begin{array}{l}0.531 \\
(0.155)\end{array}$ & $\begin{array}{l}0.679 * * * \\
(0.172)\end{array}$ \\
\hline LABDENSITY & $\begin{array}{l}0.352 * * * \\
(0.080)\end{array}$ & $\begin{array}{l}0.354 * * * \\
(0.081)\end{array}$ & $\begin{array}{l}0.338 * * * \\
(0.084)\end{array}$ & $\begin{array}{l}0.390 * * * \\
(0.083)\end{array}$ & $\begin{array}{l}0.366 * * * \\
(0.081)\end{array}$ & $\begin{array}{l}0.373 * * * \\
(0.083)\end{array}$ & $\begin{array}{l}0.362 * * * \\
(0.080)\end{array}$ \\
\hline EDUCATION & $\begin{array}{l}-0.461 * * * \\
(0.120)\end{array}$ & $\begin{array}{l}-0.541 * * * \\
(0.159)\end{array}$ & & $\begin{array}{l}-0.301 * * \\
(0.119)\end{array}$ & $\begin{array}{l}-0.331 * * \\
(0.161)\end{array}$ & & $\begin{array}{l}-0.487 * * * \\
(0.120)\end{array}$ \\
\hline CHILD1 & & $\begin{array}{l}-0.183 \\
(0.239)\end{array}$ & $\begin{array}{l}-0.349 * * \\
(0.160)\end{array}$ & & & & \\
\hline CHILD2 & & & & $\begin{array}{l}-0.123 * * * \\
(0.027)\end{array}$ & & & \\
\hline SECSCHOOL & & & & & $\begin{array}{l}-0.112 \\
(0.092)\end{array}$ & $\begin{array}{l}-0.238 * * * \\
(0.070)\end{array}$ & \\
\hline CONVENTION & & & & & & & $\begin{array}{l}0.031 \\
(0.020)\end{array}$ \\
\hline REGIONAL DUMMIES & Yes & Yes & Yes & Yes & Yes & Yes & Yes \\
\hline Adj. $R^{2}$ & 0.35 & 0.35 & 0.28 & 0.48 & 0.35 & 0.33 & 0.36 \\
\hline $\mathrm{N}$ & 112 & 112 & 112 & 95 & 111 & 111 & 112 \\
\hline
\end{tabular}

that measure the observed extent of child labour, CHILD1, CHILD2 and SECSCHOOL, have a negative sign (columns 2, 4 and 5), but only CHILD2 is significant. The likely reason for the non-significance of CHILD1 and SECSCHOOL is the fact that both are highly correlated with EDUCATION (the partial correlations are 0.82 and 0.85 , respectively). Obviously, if children are working and/or not attending (secondary) school, they are less likely to be well educated. Since both variables appear to be close substitutes for the educational attainment index, EDUCATION has been dropped in additional regressions with CHILD1 and SECSCHOOL. Now, both child labour variables still have a negative sign and like CHILD2 are statistically significant at the 5 and 1 per cent level, respectively (columns 3 and 6). Hence, a higher level of child labour is associated with an increasing endowment of unskilled labour and an improved comparative advantage in unskilled-labourintensive goods.

The number of ratified ILO conventions on child labour seems not to significantly influence comparative advantage in exports of labour-intensive goods. The coefficient for CONVENTION is positive, which implies that a higher number of ratified conventions is positively associated with comparative advantage, but not statistically significant. 
So far, it has been assumed that child labour is exogenous with respect to FDI and comparative advantage. In the case of FDI, this assumption seems appropriate, since both the proportion of FDI inflows to the total capital stock and the proportion of workers employed in transplants of multinationals to the total labour force of a country are usually rather small. However, the question is whether the same applies to trade. Second-best trade models frequently assume that not only protectionism, but also national regulations are influenced by trade flows (Trefler, 1993). It is feasible, for instance, that if a comparative advantage in unskilledlabour-intensive commodities declines, the reaction of a government may be to reduce the stringency or enforcement of child labour regulations. Such a linkage could for that reason offset any impact of child labour on comparative advantage, and hence must be controlled for. In such a situation, it seems appropriate to estimate simultaneous equations whereby the impact of child labour on the structure of trade flows is estimated in a manner that controls for simultaneity between these two variables.

In a further set of regressions, the determinants of the extent of child labour are included. Given that child labour is above all influenced by income levels, GDP per capita is used as the key control variable. The results, reported in Table 5, show that there is little influence of trade on the extent of child labour. CHILD1 and SECSCHOOL are not statistically significant, only CHILD2 is significant, but barely, at the 10 per cent level.

In sum, the results regarding comparative advantage and child labour imply that industrialised countries do not have a economic problem with child labour in developing countries; they even "profit" from its occurrence due to lower prices for unskilled-labour-intensive goods (or improved terms of trade). On the other hand,

Table 5. Child Labour and Comparative Advantage, Child Labour Variables Treated as Endogenous Variables

\begin{tabular}{lccc}
\hline \multirow{2}{*}{$\begin{array}{c}\text { Independent } \\
\text { Variables }\end{array}$} & \multicolumn{3}{c}{ Dependent Variables: } \\
\cline { 2 - 4 } & CHILD1 & CHILD2 & SECSCHOOL \\
\hline Constant & $0.874 * * *(0.017)$ & $0.820^{* * *}(0.077)$ & $0.549 * * *(0.038)$ \\
GDP & $0.005^{* * *}(0.001)$ & $0.042^{* * *}(0.005)$ & $0.022^{* * *}(0.003)$ \\
EXPLABINT & $-0.051(0.064)$ & $-0.584 *(0.296)$ & $0.080(0.144)$ \\
Adj. $\mathrm{R}^{2}$ & 0.16 & 0.49 & 0.42 \\
$\mathrm{~N}$ & 114 & 97 & 113 \\
\hline
\end{tabular}

Notes: See Table 2; estimated using 2SLS; the sign and significance of the determinants of labourintensive exports are almost identical to those provided in Table 4 . For reasons of space, these have not been reported; *** significant at $1 \%$ level; ** significant at $5 \%$ level; * significant at $10 \%$ level. 
developing countries may suffer by using child labour, as the long-term growth prospects are diminished as a result of lower human capital levels. Developing countries that do not have a problem with child labour might also be negatively affected, since their relative comparative advantage in unskilled-labour-intensive goods is likely to erode if other countries with a similar factor endowment use child labour. Importantly, this link applies not to total export performance, but rather to the structure of trade flows.

Interestingly, the empirical results with respect to comparative advantage and FDI tend to pull in opposite directions, since the extent of child labour is negatively linked with FDI. One likely explanation for this outcome could be that multinational enterprises are highly sensitive to host country characteristics such as democratic rights or child labour. In this way, the findings presented in this paper confirm the results of recent empirical studies that have analysed the linkages between FDI and democratic rights. These studies indicate that on average multinational enterprises invest in countries, where other fundamental human and workers rights, such as basic union rights, the abolition of forced labour and no discrimination in employment, are ensured. ${ }^{26}$ On the other hand, by using child labour, domestic firms are able to increase their (national) comparative advantage in unskilled-labourintensive goods. International campaigns by non-governmental organisations against child labour are less likely to focus on these companies providing that they are not partly or fully owned by multinational enterprises or do not act as a important supplier of (semi-) manufactured goods that are to be exported for further processing in high-income OECD countries.

\section{Policy Implications and Concluding Remarks}

Summing up the empirical evidence, there seems to be no problem with FDI and child labour, but rather with the link between child labour and comparative advantages in unskilled-labour-intensive goods. This result gives rise to the question of appropriate measures to fight child labour effectively and help to avoid competitive edges (with respect to the export structure) in international trade. In the international arena, it is often argued that sanctions should be imposed on commodities from countries with poor labour standards, especially with regard to

\footnotetext{
${ }^{26}$ See Harms and Ursprung (2002) for an empirical study on the linkages between FDI and democratic rights, and Chakrabarti (2001) for a survey of other empirical studies.
} 
children. Advocates of this position, typically from developed countries, argue for linking trade and core labour standards, preferably within the framework of the WTO, thereby creating incentives for developing countries to raise labour standards.

The effectiveness of trade sanctions as an instrument in the fight against child labour is highly questionable. First of all, sanctions fail to take into account that most parents send their children to work to escape extreme poverty and hunger and not because they are selfish or sloth. Rogers and Swinnerton (2001) have estimated that families cannot survive without additional income from children if GDP per worker falls below US $\$ 5,020$. Hence, child labour as a mass phenomenon has to be distinguished from child abuse (Basu, 1999). Secondly, this instrument focuses only on export industries and does not tackle the child labour problem in other areas. Putting both arguments together, trade sanctions are likely to drive children to other sectors with potentially even lower labour standards, such as child prostitution. There is evidence that in Bangladesh children were thrown out of their jobs in the garment industry as a result of U.S. boycott pressures, with most ending up in far more dangerous employment: welding shops and prostitution. ${ }^{27}$

Furthermore, there is evidence that greater market integration is associated with lower levels of child labour (Figure 2). The partial correlations between the degree

Figure 2. Extent of Child Labour and Market Integration.

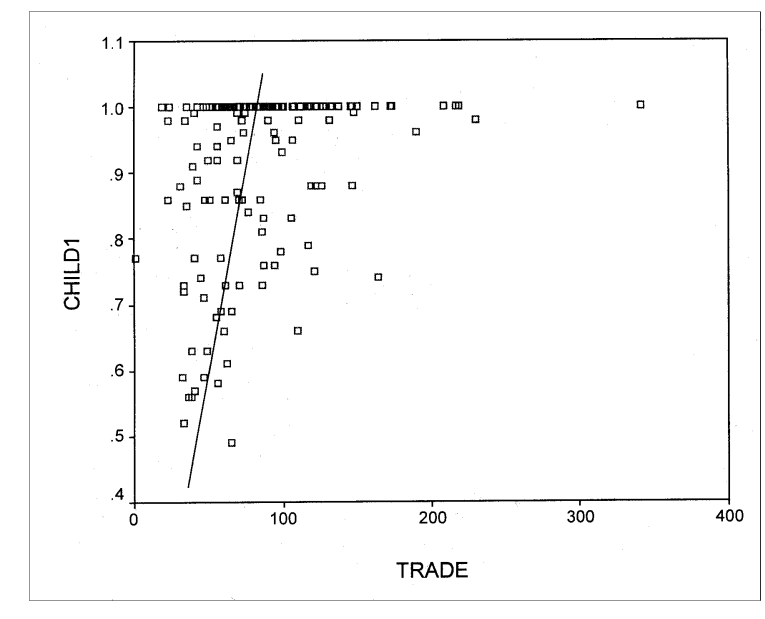

Note: Both variables refer to the year 2000. TRADE refers to the ratio of total imports and exports to GDP. See Appendix A for data sources. 
f market integration (in the analysis, the variable has been labelled TRADE) and the three indicators that measure the extent of child labour, CHILD1, CHILD2 and SECSCHOOL, are $0.33,0.34$ and 0.27 , respectively, indicating positive correlations in the medium range. The positive correlations imply that the extent of child labour is negatively associated with openness to trade. This result is basically in line with the empirical evidence presented by earlier studies, such as Shelburne (2001) or Edmonds and Pavcnik (2002). ${ }^{28}$

If the negative linkage between child labour and openness to trade is accepted, trade sanctions are ineffective or even counter-productive as a remedy for child labour. Thus, the inclusion of labour standards, especially those concerning child labour, in the rules and mandate of the WTO is not appropriate. Their enforcement may even be abused by richer countries to protect their markets against goods from developing countries with poorer standards, thereby compromising the economic development of low-income countries.

Another approach that has found increasing support is to inform the consumer about the conditions under which goods are produced via product labelling. This policy uses the market mechanism and leaves the decision of whether or not to boycott a product made with child labour to the consumer. ${ }^{29}$ Although appealing on first sight, product labelling suffers from several weaknesses. Firstly, firms face an incentive to exaggerate the labour conditions in their workplace. Even if one can circumvent this information problem, labour standards and conditions of work are unlikely to be represented accurately on simple labels (Rodrik, 1996). Finally and probably most important, product labelling shares problems with trade sanctions as it attacks child labour only in a few export-goods sectors and, hence, may push children into even more harmful activities.

In order to fight child labour effectively, people in the developed countries have to realise that child labour cannot be simply banned by legal action without pushing poorer households into even greater poverty. As the example of the dismissed children in Bangladesh shows, child labour cannot be abolished at once

\footnotetext{
${ }^{28}$ Focussing on the determinants of child labour, Shelburne (2001) found that trade openness reduces the benefits of child labour to other members of the society and, thus, the incentive to use children as workers. In an extensive case study, Edmonds and Pavcnik (2002) came to the conclusion that the economic integration of Vietnam into the international trading community in the 1990s reduced the prevalence of child labour significantly. The income of adults (parents) went up due to a real increase in the price of the exported good (rice), thereby reducing the need to rely on child labour for parents.

${ }^{29}$ See Freeman (1994) for a detailed discussion on the issue.
} 
but must be abandoned in a planned and phased manner. Activities have to contain economic incentives for families to pull their children out of the labour force. For instance, school meals or subsidies can make it more attractive for parents to send their children to school. Industrialised nations and international organisations can contribute to the financing of such efforts. In contrast to sanctions and other punishments that take away choices, incentive schemes open up new and improved alternatives to families without taking away existing choices. For the success of such programmes, it is important that education subsidies replace a significant part of the childs contribution to family income.

A second ingredient of an effective policy against child labour is to promote the development of functioning credit markets in developing countries and to facilitate the access to these markets for poorer households. With access to capital markets, parents will arguably allocate more of their childrens time to education, since they will be able to shift wealth from the future to the present by borrowing against future income. In contrast, the absence of functioning credit markets leaves the parents without any choice but to put children at work and results in inadequate human capital formation. ${ }^{30}$

Moreover, in the area of international labour standards, one must distinguish universally applicable standards from those depending on the level of development of a country. Beyond any doubt, every country should adhere to some basic standards, such as the ban of any form of forced child labour. The fundamental rights at work as defined by the ILO can be considered as a reasonable set of minimal labour standards, although the effective abolition of child labour should be regarded as a target for the long run. While some labour standards are universal, other standards should clearly allow for differences in the level of development of a country. Historically, labour standards have risen with economic progress. Hence, several standards, such as minimum wages or the minimum age for admission to employment, depend on a nations productive capacity and should be scaled according to this capacity. Poorer countries simply cannot afford to "buy" the same labour standards as advanced countries and would be adversely affected by them.

Nevertheless, as mentioned earlier, there is some scope for international labour standards in general as well as with regard to the problem of child labour. This raises the question of who should monitor compliance to these standards. From our

\footnotetext{
${ }^{30}$ Jafarey and Lahiri (2002) provide a theoretical analysis of the role of credit markets in the fight against child labour.
} 
point of view, the enforcement of international labour standards should be left to the ILO for several reasons. First of all, the ILO already plays a very important role in the promotion of fundamental working rights through technical assistance, arguably the most effective instrument to achieve compliance to labour standards. In the case of child labour, the IPEC, run by the ILO, has been at the forefront of international efforts to tackle the problem. Next, a very large number of different countries are organised in the ILO. Finally, the use of ILO conventions, which nations are encouraged to sign and are required to comply to, is anything but a powerless instrument.

In an increasingly interconnected world, countries are likely to be adversely affected by the violation of convention. For instance, multinationals fear reputation effects and, hence, will refrain from investment in those countries, as the empirical evidence presented in this paper shows. If necessary, ILO conventions can also be backed by punitive action. Article 33 of the ILO constitution provides an appropriate instrument, authorising the ILO to take actions against member states that do not comply with recommendations made by a Commission of Inquiry established to examine grave violations of the conventions. It would be desirable, however, to put the provision in more concrete terms by substantiating possible measures. Finally, to achieve the largest feasible reduction in child labour, action should not be product-specific or related to export industries only, as this might simply drive children from one sector into another, but rather country-specific. If sanctions are considered, these should include to widest possible range of economic instruments, such as restrictions on trade in general, FDI, or capital controls. Yet the experience of such restrictions in the past, for instance in South Africa, suggests that they are not likely to have to desired outcome (Hufbauer et al., 1990).

Received 22 January 2003, Accepted 12 August 2003

\section{References}

Amnesty International (2002), Business and Human Rights: A Geography of Risk, London: Amnesty International.

Bales, Kevin (1999), Disposable People: New Slavery in the Global Economy, Berkeley, California: University of California Press.

Bales, Kevin (2000), "Expendable People: Slavery in the Age of Globalization”, Journal of International Affairs, Vol. 53, No. 2, pp. 461-484. 
Baland, Jean-Marie and Robinson, James (2000), “Is Child Labor Inefficient?" Journal of Political Economy, Vol. 108, No. 4, pp. 662-679.

Barro, Robert (1997), Determinants of Economic Growth: A Cross-Country Empirical Study, Cambridge, MA: MIT Press.

Basu, Kaushik and Van, Pham Hoang (1998), "The Economics of Child Labor", American Economic Review, Vol. 88, No. 3, pp. 412-427.

Basu, Kaushik (1999), „International Labor Standards and Child Labor“, Challenge, Vol. 42, No. 5, pp. 80-93.

Brown, Drusilla (2000), International Trade and Core Labour Standards: A Survey of the Literature, OECD Labour Market and Social Policy Occasional Papers No. 43, Paris: OECD.

Brown, Drusilla; Deardorff, Alan and Stern, Robert (2001), Child Labor: Theory, Evidence and Policy, University of Michigan Discussion Paper No. 474.

Busse, Matthias (2002), "Do Labor Standards Affect Comparative Advantage in Developing Countries?" World Development, Vol. 30, No. 11, pp. 1921-1932.

Chakrabarti, Avik (2001), "The Determinants of Foreign Direct Investment: Sensitivity Analyses of Cross-Country Regressions", Kyklos, Vol. 54, No. 1, pp. 89-113.

Cigno, Alessandro; Rosati, Furio and Guarcello, Lorenzo (2002), "Does Globalisation Increase Child Labor?" World Development, Vol. 30, No. 9, pp. 1579-1589.

Cooke, William and Noble, Deborah (1998), "Industrial Relation Systems and US Foreign Direct Investment Abroad", British Journal of Industrial Relations, Vol. 36, No. 4, pp. 581-609.

Edmonds, Eric and Pavcnik, Nina (2002), Does Globalization Increase Child Labor? Evidence from Vietnam, NBER Working Paper Series No. 8760.

Freedom House (2002), Freedom in the World: The Annual Survey of Political Rights and Civil Liberties 2000-2001, New Brunswick: Transaction Publications.

Freeman, Richard (1994), "A Hard-headed Look at Labour Standards", in Werner Sengenberger and Duncan Campbell (eds.), International Labour Standards and Economic Interdependence, Geneva: ILO, pp. 117-157.

Graham, Edward (2000), Fighting the Wrong Enemy: Antiglobal Activists and Multilateral Enterprises, Washington, DC: Institute for International Economics.

Harms, Philipp and Ursprung, Heinrich (2002), "Do Civil and Political Repression Really Boost Foreign Direct Investment?" Economic Inquiry, Vol. 40, No. 4, pp. 651-663.

Helliwell, John (1994), "Empirical Linkages Between Democracy and Economic Growth", British Journal of Political Science, Vol. 24, pp. 225-248.

Hussain, Mahmood (1999), Child Labor Standards and Economic Growth: An Econometric Analysis, Working Paper No. 99-21, University of Colorado.

Hufbauer, Gary Clyde; Schott, Jeffrey and Elliot, Kimberley Ann (1990), Economic Sanctions Reconsidered, History and Current Policy, Second Edition, Washington, DC: Institute for International Economics.

ILO (1989), Constitution of the International Labour Organisation and Standing Orders of the International Labour Conference, Geneva: ILO. 
ILO (1998), ILO Declaration on Fundamental Principles and Rights at Work and its Follow-up, Geneva: ILO.

ILO (2002), A Future Without Child Labour, International Labour Conference $90^{\text {th }}$ Session 2002, Report I (B), Geneva: ILO.

ILO (2003), Ratifications of the ILO Fundamental Conventions, Internet Posting: http:// webfusion.ilo.org/public/db/standards/normes/appl/appl-ratif8conv.cfm?Lang=EN

ITC (2002), Trade Analysis System PC-TAS, ITC (International Trade Center) and United Nations Statistics Division, Trade Data on CD-ROM.

Jafarey, Saqib and Lahiri, Sajal (2001), "Will Trade Sanctions Reduce Child Labour? The Role of Credit Markets", Journal of Development Economics, Vol. 68, No. 1, pp. 137-156.

Kucera, David (2002), "Core Labour Standards and Foreign Direct Investment", International Labour Review, Vol. 141, No. 1/2, pp. 31-69.

Mah, Jai (1997), "Core Labor Standards and Export Performance in Developing Countries", The World Economy, Vol. 20, No. 6, pp. 773-785.

OECD (1996), Trade, Employment and Labour Standards: A Study of Core Workers Rights and International Trade, Paris: OECD.

OECD (2000), International Trade and Core Labour Standards, Paris: OECD.

OECD (2001), OECD Science, Technology and Industry Scoreboard: Towards a Knowledge-based Economy, Paris: OECD.

Palley, Thomas (2002), "The Child Labor Problem and the Need for International Labor Standards", Journal of Economic Issues, Vol. 36, No. 3, pp. 601-615.

Drake, Elizabeth and Lee, Thea (1999), The Case for Core Labor Standards in the International Economy: Theory, Evidence, and a Blueprint for Implementation, Economic Policy Paper E041, Public Policy Department, Washington, DC: AFLCIO.

Rodrik, Dani (1996), "Labor Standards in International Trade: Do They Matter and What Do We Do About Them?" In Robert Z. Lawrence, Dani Rodrik and John Whalley (eds.), Emerging Agenda For Global Trade: High States for Developing Countries, Baltimore: Johns Hopkins University Press, pp. 35-79.

Rogers, Carol Ann and Swinnerton, Kenneth (2001), Inequality, Productivity, and Child Labor: Theory and Evidence, Georgetown University Working Paper.

Rybczynski, Tadeusz (1955), "Factor Endowment and Relative Commodity Prices", Economica, Vol. 22, pp. 36-41.

Sala-i-Martin, Xavier (1997), "I Just Ran Two Million Regressions", American Economic Review, Vol. 87, No. 2, pp. 178-83.

Shelburne, Robert (2001), "An Explanation of the International Variation in the Prevalence of Child Labour", The World Economy, Vol. 24, No. 3, pp. 359-378.

Trefler, Daniel (1993), "Trade Liberalization and the Theory of Endogenous Protection: An Econometric Study of US Import Policy", Journal of Political Economy, Vol. 101, No. 1, pp. 138-160.

Tyres, Rodney; Phillips, Prue and Findlay, Christopher (1987), “ASEAN and China 
Exports of Labor-intensive Manufactures: Performance and Prospects”, ASEAN Economic Bulletin, Vol. 3, No. 3, pp. 339-367.

UNCTAD (2002), World Investment Report 2002, New York and Geneva: United Nations. UNDP (2002), Human Development Report 2002, Geneva: UNDP.

UNICEF (1997), The State of the Worlds Children 1997, Oxford: Oxford University Press. US Department of State (2002), The Department of Labor's 2001 Findings on the Worst Forms of Child Labor, Washington, DC: US Government Printing Office.

World Bank (2002), World Development Indicators, Data on CD-ROM, Washington, DC: World Bank. 


\section{Appendix A: Definition of Variables and Data Sources}

\begin{tabular}{|c|c|c|}
\hline Variable & Definition & Source \\
\hline FDI & $\begin{array}{l}\text { Foreign direct investment per capita, net inflows } \\
\text { in current US dollars, annual average for the } \\
\text { period } 1995-2000\end{array}$ & World Bank (2002) \\
\hline GDP & GDP per capita in current US dollars (000), 2000 & World Bank (2002) \\
\hline GROWTH & $\begin{array}{l}\text { Growth of GDP per capita in per cent, annual } \\
\text { average for the period } 1995-2000\end{array}$ & World Bank (2002) \\
\hline TRADE & Total ex- and imports divided by GDP, 2000 & World Bank (2002) \\
\hline DEMOCRACY & $\begin{array}{l}\text { Index for political rights and civil liberties, index } \\
\text { from } 0-1,2000\end{array}$ & $\begin{array}{l}\text { Freedom House (2002) } \\
\text { and own calculations }\end{array}$ \\
\hline EXPLABINT & $\begin{array}{l}\text { Exports of unskilled-labour-intensive manufac- } \\
\text { tured goods divided by total exports of goods, } \\
2000\end{array}$ & ITC (2002) \\
\hline LABDENSITY & $\begin{array}{l}\text { Total labour force divided by land area (1,000 sq. } \\
\mathrm{km} \text { of land), } 2000\end{array}$ & World Bank (2002) \\
\hline EDUCATION & $\begin{array}{l}\text { Educational attainment index, based on average } \\
\text { years of schooling in the above- } 25 \text { population } \\
\text { and illiteracy rate, index from } 0-1,2000\end{array}$ & UNDP (2002) \\
\hline CHILD1 & $\begin{array}{l}\text { Percentage of children, ages } 10-14 \text {, who are not } \\
\text { working, } 2000\end{array}$ & $\begin{array}{c}\text { ILO (2002), } \\
\text { World Bank (2002) }\end{array}$ \\
\hline CHILD2 & Indicator for child labour, scale from $0-2,2000$ & $\begin{array}{c}\text { Rodrik (1996), } \\
\text { ILO (2002), } \\
\text { US Depart. of State } \\
\text { (2002) }\end{array}$ \\
\hline SECSCHOOL & $\begin{array}{l}\text { Gross secondary school enrolment rate in per } \\
\text { cent, } 2000\end{array}$ & World Bank (2002) \\
\hline CONVENTION & $\begin{array}{l}\text { Number of ratifications of the two fundamental } \\
\text { ILO conventions on child labour No. } 138 \text { and } \\
\text { No. } 182 \text {, Dec. } 2002\end{array}$ & ILO (2003) \\
\hline $\begin{array}{l}\text { REGIONAL } \\
\text { DUMMIES }\end{array}$ & $\begin{array}{l}\text { Full set of six regional dummy variables: (1) } \\
\text { Sub-Saharan Africa, (2) Asia \& the Pacific, (3) } \\
\text { Middle East \& North Africa, (4) Latin America } \\
\& \text { the Caribbean, (5) USA, Canada, Western } \\
\text { Europe, Australia \& New Zealand; (6) Transition } \\
\text { economies }\end{array}$ & \\
\hline
\end{tabular}




\section{Appendix B: Assigned Numbers for CHILD2}

Indicator $=2$

Austria, Bahrain, Barbados, Belgium, Canada, Denmark, Finland, France, Gabon, Germany, Hungary, Iceland, Ireland, Japan, Luxembourg, Malaysia, Malta, Netherlands, New Zealand, Norway, Oman, Seychelles, Singapore, Korea (Republic), Suriname, Sweden, Switzerland, United Kingdom, United States

Indicator $=1$

Algeria, Argentina, Australia, Bahamas, Brazil, Burundi, Burkina Faso, Cameroon, Central African Republic, Chad, Chile, China, Colombia, Cote d'Ivoire, Dominican Republic, Ecuador, El Salvador, Ethiopia, Fiji, Gambia, Ghana, Greece, Guatemala, Guinea, Guyana, Honduras, India, Indonesia, Iran, Israel, Italy, Jamaica, Jordan, Liberia, Lithuania, Mauritania, Mauritius, Mexico, Morocco, Mozambique, Nicaragua, Niger, Pakistan, Panama, Papua New Guinea, Peru, Philippines, Poland, Portugal, Romania, Saudi Arabia, Senegal, South Africa, Spain, Sri Lanka, Swaziland, Togo, Trinidad and Tobago, Turkey, United Arab Emirates, Uruguay, Venezuela, Zambia, Zimbabwe

Indicator $=0$

Albania, Bangladesh, Benin, Bolivia, Botswana, Cambodia, Costa Rica, Egypt, Haiti, Kenya, Lesotho, Madagascar, Malawi, Mali, Myanmar, Nepal, Nigeria, Paraguay, Rwanda, Sierra Leone, Sudan, Syria, Tanzania, Thailand, Tunisia, Uganda

Sources and Definition: See text and Appendix A.

\section{Appendix C: Low Technology and Labour-intensive Goods}

\begin{tabular}{c|c}
\hline Commodity & SITC, Rev. 3 \\
\hline Textile yarn and fabric & 65 \\
Glass, glassware and pottery & $664-666$ \\
Furniture and bedding & 82 \\
Travel goods and handbags & 83 \\
Apparel & 84 \\
Footwear & 85 \\
Baby carriages, games, toys, sporting goods & 894 \\
\hline
\end{tabular}

Sources: OECD (2001), Tyres et al. (1987) and own assembly; see text for explanation. 